\title{
O Presidente Emílio Garrastazu Médici e os Problemas do Nordeste
}

\author{
Discurso do Chefe da Nação, a 6 de julho de 1970, encerrando \\ a Reuniäo do Conselho da SUDENE.
}

"Aqui vim para ver, com os olhos da minha sensibilidade, a sêca dêste ano, e vi todo o drama do Nordeste. Vim ver a sêca de 70 , e vi o sofrimento e a miséria de sempre.

Agradeço a Deus a inspiração de fazer esta viagem de emergência: uma viagem inesperada, de flagrante, apressada, parando um pouco em cada lugar, para ver as coisas e os homens que eu queria ver.

Vim ver e vi. Vi o Nordeste de dentro, dos sertões secos de Crateús e dos Currais Novos. Vi a paisagem árida, as plantações perdidas, os lugarejos mortos. Vi a poeira, o sol, o calor, a inclemência dos homens e do tempo, a desolação.

$\mathrm{Vi}$ as frentes de trabalho, feitas só para assistir o homem. Vi os postos de alistamento dessas mesmas frentes, com multidões famintas angustiadas, esperando a sua vez.

Vi o homem. Falei a êsse flagelado. $V_{i}$ seus farrapos, apertei a sua mão, vi 0 que comia, perguntei pelos seus, por sua terra, seu trabalho, seu patrão; vi homens comendo só feijão e farinha, sem tempêro e sem sal. E dizer-se que $v i$ isso em terra de salinas.

Vi o sofrimento de homens moços, de mais de 10 filhos, nunca menos de cinco, deixados lá longe, onde não cheguei a ir. Vi crianças desassistidas ao longo do caminho.

$\mathrm{Vi}$ a tôsca tapera dos homens que tiveram a sorte de alistar-se nas frentes de trabalho e pensei nos que nem chegaram até ali.

Vi a mão verde-oliva dos companheiros do Exército - do soldado ao general - estendida a êsse homem, como estrutura atuante de assistência social.

Vi como os homens se vinculam à terra, vinculados aos seus donos. Vi essa pobre lavoura de sustento, sem água, sem técnica, sem adubo, sem produtividade, desenganada de dar o esperado fruto. $E$, pior que isso, vi a angústia dos meses que ainda virão sem chuva. 
Mas vi, em tôda a parte dos sertões por onde andei, o espírito de religiosidade, a resignação, a bondade, o apêgo à família. Vi a esperança, apesar de tudo, e a fortaleza moral daquela gente sofrida que a mim falou sua verdade.

E sei que muito mais não vi. Não vi outras frentes de trabalho, mais carentes de organização e de recursos, nem os lugares onde frentes nem chegaram a se fazer. Não vi as famílias flageladas, que ficaram longe e sem fôrças, que não vieram buscar a esperança distante.

$\mathrm{Vi}$ tudo isso com os meus próprios olhos e concluí o que não cheguei a ver. Nada, em tôda a minha vida, me chocou assim e tanto me fêz emocionar e desafiar minha vontade.

Trouxe comigo, para tôdas as providências, os meus Ministros da Fazenda, da Agricultura, do Planejamento, dos Transportes e do Interior. Se, dos Ministérios do Trabalho e da Saúde, vieram só representantes, é que mandei os titulares em missão ao exterior. A tudo viram, a meu lado, o superintendente da SUDENE, os diretores do DNOCS e do Banco do Brasil, os Generais comandantes do IV Exército e do Grupamento de Engenharia, assim como os Chefes dos Gabinetes Civil e Militar da Presidência, o Chefe do SNI, os meus assessôres imediatos e os profissionais da imprensa que eu trouxe do Sul.

Sabemos todos que tudo isso já foi muito pior no Nordeste, antes da SUDENE, antes da Revolução. Sabemos que a sêca já foi indústria que enriqueceu muita gente. Sabemos que a corrupção já se saciou dêsse flagelo e que tanto demagogo fêz da miséria do sertanejo a bandeira da subversão.
Sabemos que, noutros tempos, não havia sequer uma estrutura capaz de organizar e assistir. Sabemos que já vai longe a época em que tôda estratégia consistia em obter recursos extraordinários do Govêrno Federal que, longe de chegarem aos necessitados, se perdiam em iniciativas ingênuas e estéreis, ou mesmo sob tôdas as formas de desonestidade.

Forçoso é que se diga, porém, que o quadro que nós vimos não é o quadro que devemos ver, quaisquer que sejam as desventuras, as calamidades e as inclemências da natureza. Forçoso é que nenhum de nós se conforme com essa triste realidade.

$E$ se tudo isso vi, é preciso que eu diga que houve quem me aconselhasse a que eu não viesse ver.

É preciso dizer também que vi quem lamentasse o êxodo dos flagelados para as zonas úmidas, só porque isso iria diminuir o censo e, portanto, prejudicar a representação política.

Vi, também, a multiplicidade e a superposição de órgãos de natureza $e$ escalöes diversos, atropelando-se nas providências e prejudicando a indispensável unidade de comando para a ação.

Vi muita preocupação de que eu não visse nada, e que só visse e ouvisse os poderosos da terra.

Sei, também, que, desgraçadamente, tantos dos que se queixam da falta de meios para vencer o flagelo, dilapidam preciosos recursos em propaganda $e$ no empreguismo fácil que, se nem sempre Ihes assegura vitórias eleitorals, sempre compromete a administraçăo nos anos que hão de vir.

Com o velho hábito de comandante de tropa que vela pelo seu último sol- 
dado, o Chefe da Nação não pode compreender a existência de compatriotas seus sobrevivendo em condições tão precárias.

Não, não me conformo. Isso não pode continuar.

Que fazer então, se não há milagre que transforme tudo agora mesmo, nem ao menos o milagre que tire o egoísmo do coração dos homens?

Há providências a tomar imediatamente, no mínimo para remediar tanta coisa que já deveria ter sido feita. E há coisas para fazer depois, para que - Nordeste um dia não seja mais assim.

Agora é levar comida a quem tem fome, com o abastecimento de gêneros essenciais à área atingida.

Agora é dar trabalho, dar um trabatho qualquer, para que o homem se sinta válido, com uma garantia de recursos para as frentes, nisso colaborando todos os Estados - não só os da região, com ênfase para as obras de infra-estrutura, de rodovias e de irrigação.

Agora é antecipar recursos, inclusive os recursos do Fundo Especial para os' Estados do Nordeste, não para que se malbaratem em mãos inadequadas ou em projetos enganadores, mas para projetos essenciais e de execução imediata, que cheguem logo ao homem. sob a forma de teto, de roupa, de co. mida, de água, de esgôto e de remédio.

Que fazer, então, de mais duradouro e definitivo?

Há quem pense ser possível a solução do problema das regiões semiáridas do Nordeste com a retirada, por decretos, das populações, esquecidos do amor à terra que essa gente tem.
Há quem pense que tudo se resume em redistribuir a terra, como se êsse homem assim tivesse condições de lhe dar a produtividade que ela não tem.

Há quem pense que tudo se resume na farta distribuição de créditos extraordinários aos governos estaduais $\theta$ municipais, assim como aos donos da terra, sem que se apercebam dos perigos da pulverização de recursos $\theta$ dos descaminhos que impedem que êles cheguem ao homem que sofre, chegando, no melhor, ao chafariz da praça.

Há quem pense que tudo se resume em irrigação, sem se dar conta do preço da solução nas dimensões necessárias.

E há, ainda, os que não pensam em solução nenhuma, só pensam em protesto, para acenderem a revolução social, que nos iria desunir a todos, sacrificar gerações, agravar a miséria e retardar o encontro de nosso caminho.

Então, se devemos ter sensibilidade para sentir o problema todo, devemos também ter os pés no chão e os olhos à frente para prever o desdobramento do futuro.

É certo que não podemos deixar as coisas como estão; é certo que precisamos de corrigir desvios e distorções, erros de cálculo e de perspectiva, mas não podemos pulverizar recursos, sufocar a nascente indústria nordestina, nem subverter as estruturas, ou prejudicar a notável recuperação econômica do País.

O que podemos fazer, em prazo menos iminente, é ajustar os planejamentos à realidade, é contribuir para a mudança da mentalidade político-administrativa também aqui no Nordeste. 
Decidi, então, fortalecer a agricultura nordestina, para torná-la resistente às sêcas, empenhando recursos substanciais, até de origem externa, em programas de irrigação em áreas selecionadas.

Decidi canalizar, também, consideráveis recursos de incentivos fiscais para a execução de projetos agrícolas, onde quer que se configure uma clara perspectiva de produtividade, o que implicará no fortalecimento das instituições de pesquisa agricola.

Decidi incentivar a programação de colonização em zonas úmidas do Nordeste, do Maranhão, do Sul do Pará, do Vale do São Francisco e do Planalto Central, de forma a absorver as populações de áreas consideradas totalmente desaconselháveis à vida humana.

Estou seguro de que, no campo político-administrativo, poderei contar, no próximo ano, com uma equipe de governantes estaduais e municipais, também como agora, perfeitamente sintonizada com os diretores de organismos com jurisdição na área, com os chefes militares e com os meus próprios Ministros, de tal forma que a orientação que de mim se emane converta em verdade, na desejada unidade de comando.

Ao fim desta viagem, de que retorno ainda mais determinado a cumprir minha missão, quero dizer ao povo do Nordeste que não the prometo nada, não prometo milagres, nem transmutação, nem dinheiro, nem favores, nem peço sacrifícios, nem votos, nem mobilizo a caridade. Só digo é que tudo isso tem de começar a mudar.

Exijo a contribuição da Nação inteira, a determinação dos governantes, - espírito público, a firmeza de todo chefe. Exijo a austeridade de todos os homens responsáveis, para que não haja indiferença ao sofrimento e à fome. Exijo que se diga e que se mostre sempre a verdade, por mais que ela nos doa.

Apelo à imprensa de meu País para que aponte o que de bem e mal houver, sem preocupar-se tanto com $0 \mathrm{im}$ pacto e o sensacionalismo.

Apelo à mocidade, para que não malbarate sua generosidade e sua energia, buscando objetivos que não levam a nada, mas que se junte aos homens que, em verdade, estão preparando o Brasil de seu amanhã.

Apelo à consciência nacional, para que todos os brasileiros sintam que 0 Nordeste não é um problema distante, não pertence só ao nordestino, mas é um problema nacional, que toca a sensibilidade e o brio de todos nós.

E hoje, nesta cidade do Recife, perante governadores e ministros, pensando no povo, particularmente no povo nordestino, quero dizer que năo me sinto com podêres e dons para fazer milagres, mas tenho firmeza, confiança e decisão, para proclamar à Nação inteira que, com a ajuda de todos os brasileiros e com a ajuda de Deus, 0 Nordeste afinal haverá de mudar." 